$$
\text { ANLTTD/RP--91011 }
$$

\title{
NEUTRONIC PERFORMANCE OF HIGH-DENSITY LEU FUELS IN WATER-MODERATED AND WATER-REFLECTED RESEARCH REACTORS
}

\author{
M. M. Bretscher and J. E. Matos \\ Argonne National Laboratory \\ 9700 South Cass Avenue \\ Argonne, Illinois 60439 \\ July 1996
}

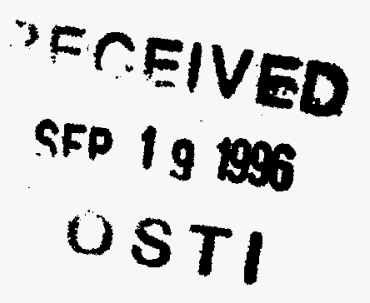

Introduction

At the Reduced Enrichment for Research and Test Reactors (RERTR) meeting in September 1994, Durand reported ${ }^{1}$ that the maximum uranium loading attainable with $\mathrm{U}_{3} \mathrm{Si}_{2}$ fuel is about $6.0 \mathrm{~g} \mathrm{U} / \mathrm{cm}^{3}$. The French Commissariat à l'Energie Atomique (CEA) plan to perform irradiation tests with 5 plates at this loading. Compagnie pour L'Etude et La Realisation de Combustibles Atomiques (CERCA) has also fabricated a few uranium nitride (UN) plates with a uranium density in the fuel meat of $7.0 \mathrm{~g} / \mathrm{cm}^{3}$ and found that $U N$ is compatible with the aluminum matrix at temperatures below $500^{\circ} \mathrm{C}$.

High density dispersion fuels proposed for development include $U-\operatorname{Zr}(4 \quad w t \%)-\mathrm{Nb}(2 \quad w t \%), U$ $\mathrm{Mo}(5 \mathrm{wt} \%)$, and U-Mo(9 wt\%). The purpose of this note is to examine the relative neutronic behavior of these high density fuels in a typical light water-reflected and water-moderated MTR-type research reactor.

\section{Assumed Properties of the High Density Dispersion Fuels}

Table 1 briefly summarizes the properties of these uranium dispersants. In this table $\rho_{D}$ is the density of the dispersant and $W_{U}$ is the weight fraction of uranium in the fuel particle. Since data is not available, it was assumed that the porosity $(P)$ dependance on the volume fraction of the dispersant in the fuel meat $\left(N^{D}\right)$ follows approximately the same relation as that found for $\mathrm{U}_{3} \mathrm{Si}_{2}$, namely (see Ref. 2),

$$
P=0.072 V F^{D}-0.275\left(V F^{D}\right)^{2}+1.32\left(V F^{D}\right)^{3} .
$$

This relation accounts for the observed porosity of the UN test plates ${ }^{1}$.

Dispersant volume fractions corresponding to $\mathrm{U}_{3} \mathrm{Si}_{2}$ and $\mathrm{UN}$ fuel plates with uranium loading of 6.0 and $7.0 \mathrm{~g} / \mathrm{cm}^{3}$, respectively, are $53.1 \%$ and $51.9 \%$. These values represent a practical upper limit for usable volume fractions. Figure 1 shows dispersant volume fractions as a function of uranium density in the fuel meat for each fuel type. With a maximum volume fraction of $52-53 \%$, this graph allows one to estimate the maximum uranium density in the fuel meat that may be achieved for each fuel.

\section{Fuel Element, Cross Sections, and Reactor Model}

An 18-plate fuel element design, similar to that used in the University of Michigan's Ford Nuclear Reactor (FNR) was used for this study. The fuel meat, Al-6061 clad, and water channel thicknesses were assumed to be $0.020,0.015$, and 0.127 inch, respectively. Using the 


\section{DISCLAIMER}

This report was prepared as an account of work sponsored by an agency of the United States Government. Neither the United States Government nor any agency thereof, nor any of their employees, makes any warranty, express or implied, or assumes any legal liability or responsibility for the accuracy, completeness, or usefulness of any information, apparatus, product, or process disclosed, or represents that its use would not infringe privately owned rights. Reference herein to any specific commercial product, process, or service by trade name, trademark, manufacturer, or otherwise does not necessarily constitute or imply its endorsement, recommendation, or favoring by the United States Government or any agency thereof. The views and opinions of authors expressed herein do not necessarily state or reflect those of the United States Government or any agency thereof. 


\section{DISCLAIMER}

Portions of this document may be illegible in electronic image products. Images are produced from the best available original document. 
WIMS code ${ }^{3}, 4$-group cross sections were generated for the fuel and for the side plate regions for each uranium density and for each fuel type. The calculations were made for LEU fuel with uranium densities in the fuel meat of $4.8,5.5,6.5,7,5$, and $8.5 \mathrm{~g} / \mathrm{cm}^{3}$. At these densities the ${ }^{235} U$ fuel element masses are $317.8,364.1,430.3,496.5$, and 562.7 grams, respectively. The simplified hypothetical reactor consisted of a square array of fuel elements immersed in a thick pool of water. Calculations were made for $5 \times 5$ and $6 \times 6$ arrays of fresh fuel.

\section{Results and Conclusions}

For each fuel element array, core excess reactivities in $\% \Delta k / k$ are plotted as a function of uranium density for each dispersant. Figures 2 and 3 show these results. Data for each plotted point are collected in Table 2 where VFM is the volume fraction of the aluminum matrix. Figure 4 is a plot of excess reactivity vs volume fraction of the dispersed phase for the $5 \times 5$ array. These results show that a dispersion of the $\mathrm{U}-\mathrm{Zr}-\mathrm{Nb}$ alloy has the most favorable neutronic properties and offers the potential for uranium densities greater than $8.0 \mathrm{~g} / \mathrm{cm}^{3}$. On the other hand, $U N$ is the least reactive fuel because of the relatively large ${ }^{14} N(n, p)$ cross section. For a fixed value of $k_{\text {eff, }}$, the required ${ }^{235} U$ loading per fuel element is least for the $U-Z r-N b$ fuel and steadily increases for the U-Mo(5\%), U-Mo(9\%), and UN fuels. Because of volume fraction limitations, the $\mathrm{UO}_{2}$ dispersions are only useful for uranium densities below $5.0 \mathrm{~g} / \mathrm{cm}^{3}$. In this density range, however, $\mathrm{UO}_{2}$ is more reactive than $\mathrm{U}_{3} \mathrm{Si}_{2}$.

Except for uranium mononitride, none of these proposed high density fuels have been fabricated. Test results regarding the compatibility of UN and aluminum are reported in Ref. 1, but no such data is currently available for the U-Mo and U-Zr-Nb alloys. How any of these high density dispersion fuels behave under irradiation is also unknown. However, all of these stabilize the uranium by inhibiting the formation of the $\alpha$ phase. FY1996 funds have been provided to initiate the development, fabrication, and irradiation testing of these high density fuels, especially the U-Zr-Nb alloy.

\section{References}

1. J. P. Durand, P. Laudamy, and K. Richter, "Preliminary Developments of MTR Plates with Uranium Nitride," XVII International RERTR Meeting, Williamsburg, Virginia, USA, September 18-23, 1994.

2. J. L. Snelgrove, R. F. Domagala, G. L. Hofman, T. C. Wiencek, G. L. Copeland, R. W. Hobbs, and R. L. Senn, "The Use of $U_{3} S_{2}$ Dispersed in Aluminum in Plate-Type Fuel Elements for Research and Test Reactors," p. 11, ANL/RERTR/TM-11, October 1987.

3. J. R. Deen, W. L. Woodruff and C. I. Costescu, "WIMS-D4M User Manual (Rev. 0)," ANL/RERTR/TM-23, Argonne National Laboratory, Argonne, IL, July 1995. 


\begin{tabular}{|c|c|c|}
\hline \multicolumn{3}{|c|}{$\begin{array}{l}\text { Table } 1 . \\
\text { Properties of Uranium Dispersants }\end{array}$} \\
\hline Dispersant & $\rho_{D}-\mathrm{g} / \mathrm{cm}^{3}$ & $w_{u}{ }^{D}-\%$ \\
\hline $\mathrm{UO}_{2}$ & 10.9 & 88.1 \\
\hline$U_{3} \mathrm{Si}_{2}$ & 12.2 & 92.7 \\
\hline UN & 14.3 & 94.4 \\
\hline U-Mo(9 wt. \%) & 17.0 & 91.0 \\
\hline U-Zr(4 wt.\%)-Nb(2 wt.\%) & 17.3 & 94.0 \\
\hline U-Mo (5 wt.\%) & 17.9 & 95.0 \\
\hline
\end{tabular}

Fig. 1. Uranium Density vs Volume Fraction of Dispersed Phase

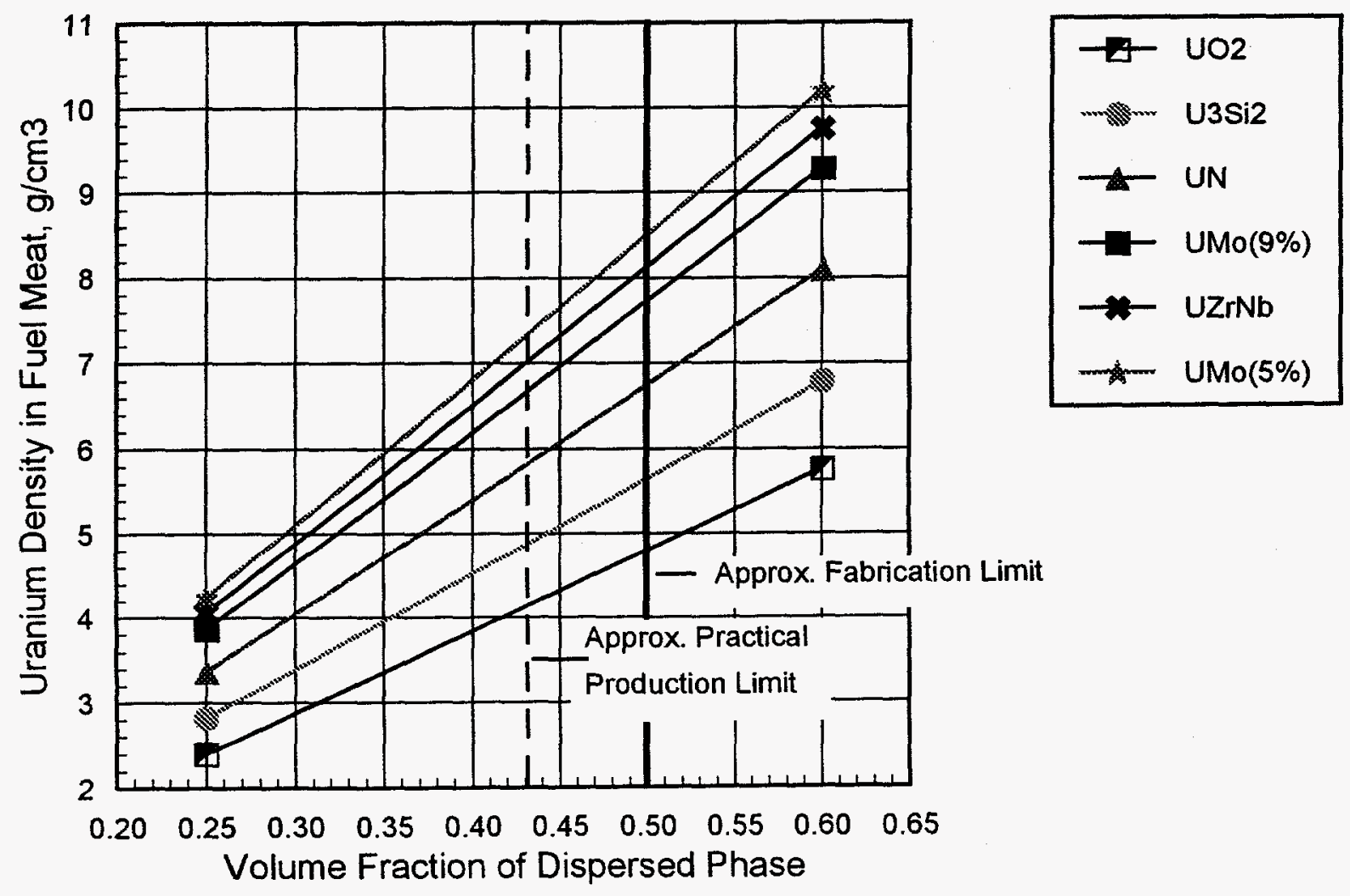


Fig. 2. High Density Fuels in FNR-Like $5 \times 5$ Core Without C-Rods
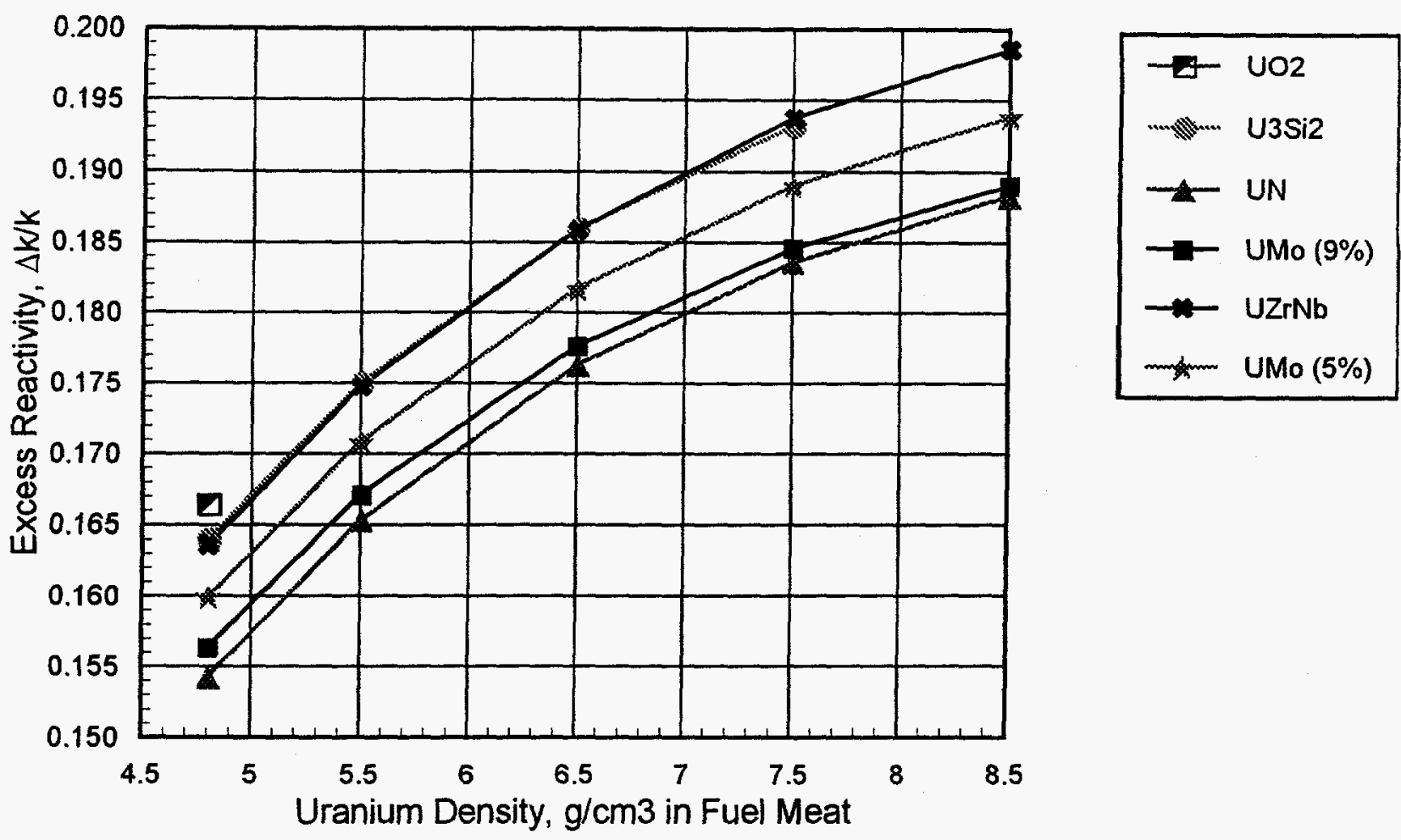

Fig. 3. High Density Fuels in FNR-Like $6 \times 6$ Core Without C-Rods

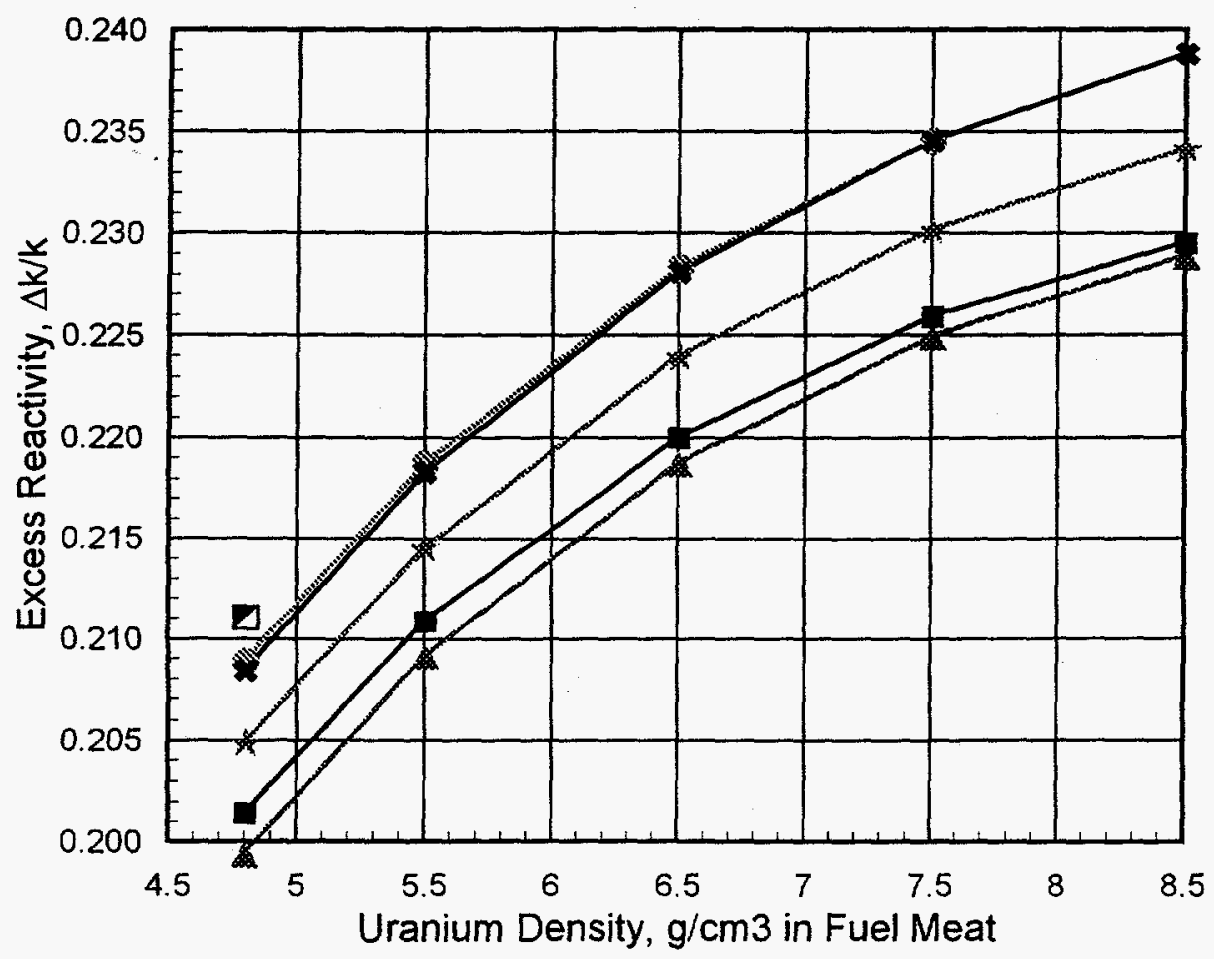

$$
\begin{aligned}
& -4 \mathrm{UO} 2 \\
& -\mathrm{U} 3 \mathrm{Si} 2 \\
& -\mathrm{UN} \\
& -\mathrm{UMO}(9 \%) \\
& -\mathrm{UZrNb} \\
& \mathrm{UMO}(4 \%)
\end{aligned}
$$




\begin{tabular}{|c|c|c|c|c|c|c|}
\hline Neutronic Perf & ce of High & $\begin{array}{c}\text { Table } \\
\text { Density }\end{array}$ & $\begin{array}{l}2 . \\
\text { LEU Fuels }\end{array}$ & in a $\mathrm{H}_{2} \mathrm{C}$ & Reflected & Core \\
\hline Dispersant & $\rho_{U}-\mathrm{g} / \mathrm{cm}^{3}$ & $V F^{D_{-} \%}$ & P-\% & $V F^{M}-\%$ & $\%$ & $\mathrm{k} / \mathrm{k}$ \\
\hline & & & & & $\begin{array}{c}6 \times 6 \\
\text { Array }\end{array}$ & $\begin{array}{l}5 \times 5 \\
\text { Array }\end{array}$ \\
\hline $\mathrm{UO}_{2}$ & 4.80 & 49.8 & 13.1 & 37.1 & 21.1 & 16.7 \\
\hline$U_{3} S_{2}$ & $\begin{array}{l}4.80 \\
5.50 \\
6.50 \\
7.50 \\
\end{array}$ & $\begin{array}{l}42.4 \\
48.6 \\
57.5 \\
66.3 \\
\end{array}$ & $\begin{array}{c}8.2 \\
12.2 \\
20.1 \\
31.2 \\
\end{array}$ & $\begin{array}{l}49.4 \\
39.2 \\
22.4 \\
2.50\end{array}$ & $\begin{array}{l}20.9 \\
21.9 \\
22.8 \\
23.5\end{array}$ & $\begin{array}{l}16.4 \\
17.5 \\
18.6 \\
19.3\end{array}$ \\
\hline UN & $\begin{array}{l}4.80 \\
5.50 \\
6.50 \\
7.50 \\
8.50 \\
\end{array}$ & $\begin{array}{l}35.6 \\
40.7 \\
48.2 \\
55.6 \\
63.0 \\
\end{array}$ & $\begin{array}{c}5.0 \\
7.3 \\
11.8 \\
18.1 \\
26.6 \\
\end{array}$ & $\begin{array}{l}59.4 \\
52.0 \\
40.0 \\
26.3 \\
10.4 \\
\end{array}$ & $\begin{array}{l}19.9 \\
20.9 \\
21.9 \\
22.5 \\
22.9 \\
\end{array}$ & $\begin{array}{r}15.4 \\
16.5 \\
17.6 \\
18.4 \\
18.8 \\
\end{array}$ \\
\hline U-Mo(9\%) & $\begin{array}{l}4.80 \\
5.50 \\
6.50 \\
7.50 \\
8.50 \\
\end{array}$ & $\begin{array}{l}31.0 \\
35.6 \\
42.0 \\
48.5 \\
54.9 \\
\end{array}$ & $\begin{array}{c}3.6 \\
5.0 \\
8.0 \\
12.1 \\
17.5 \\
\end{array}$ & $\begin{array}{l}65.4 \\
59.4 \\
50.0 \\
39.4 \\
27.6 \\
\end{array}$ & $\begin{array}{l}20.2 \\
21.1 \\
22.0 \\
22.6 \\
23.0 \\
\end{array}$ & $\begin{array}{l}15.6 \\
16.7 \\
17.8 \\
18.5 \\
18.9 \\
\end{array}$ \\
\hline$U-\operatorname{Zr}(4 \%)-\mathrm{Nb}(2 \%)$ & $\begin{array}{l}4.80 \\
5.50 \\
6.50 \\
7.50 \\
8.50\end{array}$ & $\begin{array}{l}29.5 \\
33.8 \\
40.0 \\
46.1 \\
52.3\end{array}$ & $\begin{array}{c}3.1 \\
4.4 \\
6.9 \\
10.4 \\
15.1 \\
\end{array}$ & $\begin{array}{l}67.4 \\
61.8 \\
53.1 \\
43.5 \\
32.6 \\
\end{array}$ & $\begin{array}{l}20.8 \\
21.8 \\
22.8 \\
23.5 \\
23.9 \\
\end{array}$ & $\begin{array}{l}16.4 \\
17.5 \\
18.6 \\
19.4 \\
19.9 \\
\end{array}$ \\
\hline U-Mo(5\%) & $\begin{array}{l}4.80 \\
5.50 \\
6.50 \\
7.50 \\
8.50\end{array}$ & $\begin{array}{l}28.2 \\
32.3 \\
38.2 \\
44.1 \\
50.0\end{array}$ & $\begin{array}{c}2.8 \\
3.9 \\
6.1 \\
9.2 \\
13.2\end{array}$ & $\begin{array}{l}69.0 \\
63.7 \\
55.7 \\
46.7 \\
36.8\end{array}$ & $\begin{array}{l}20.5 \\
21.5 \\
22.4 \\
23.0 \\
23.4\end{array}$ & $\begin{array}{l}16.0 \\
17.1 \\
18.2 \\
18.9 \\
19.4\end{array}$ \\
\hline
\end{tabular}


Fig. 4. High Density Fuels in FNR-Like $5 \times 5$ Core Without C-Rods, Excess Reactivity vs Volume Fraction of Dispersed Phase

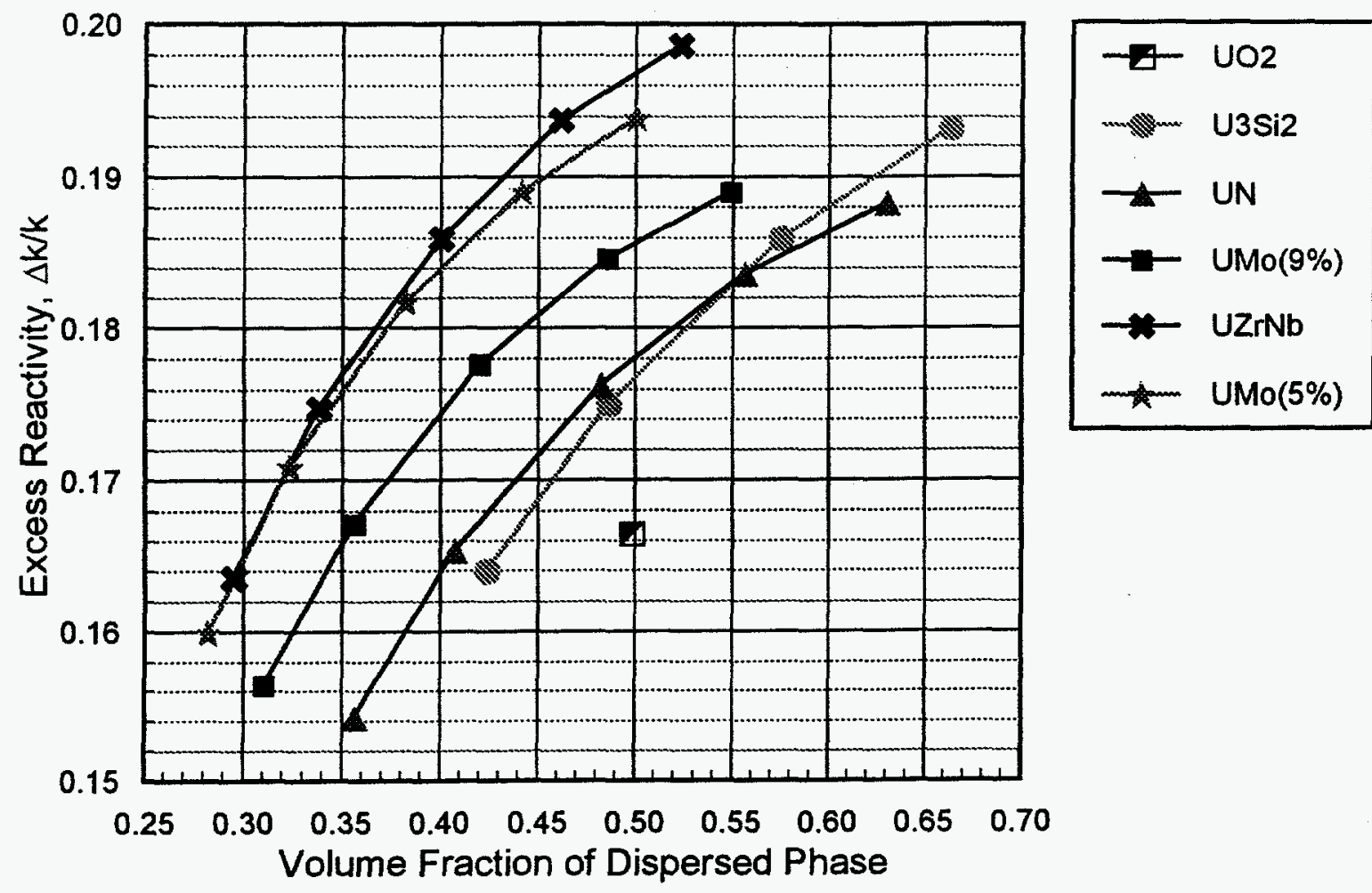

\section{DISCLAIMER}

This report was prepared as an account of work sponsored by an agency of the United States Government. Neither the United States Government nor any agency thereof, nor any of their employees, makes any warranty, express or implied, or assumes any legal liability or responsibility for the accuracy, completeness, or usefulness of any information, apparatus, product, or process disclosed, or represents that its use would not infringe privately owned rights. Reference herein to any specific commercial product, process, or service by trade name, trademark, manufacturer, or otherwise does not necessarily constitute or imply its endorsement, recommendation, or favoring by the United States Government or any agency thereof. The views and opinions of authors expressed herein do not necessarily state or reflect those of the United States Government or any agency thereof. 